\title{
$O$, say does that star spangled banner yet wave
}

Jack E. Riggs, MD, CAPT, MC, USN (Ret)

Neurology ${ }^{\circledR}$ 2018;90:1029-1031. doi:10.1212/WNL.0000000000005604

August in the Kuwait desert; I was hot, sweating profusely, and jet-lagged. And this was going to be my home for nearly a year. Even in the "air-conditioned" command tent, it was above 90 degrees. The current commanding officer was a seasoned active duty Navy Medical Corps captain. Looking calm, cool, and dry and with his legs propped up on his desk, he described for me his duties and responsibilities. I was so miserable and tired that I was having difficulty keeping my eyes open and focusing on his words. The temperature was 126 degrees Fahrenheit outside, and I was not acclimated. I had taken off the jacket of my desert cammies. My brown T-shirt was soaking wet with sweat.

Suddenly an Army lieutenant colonel stormed into the office. No knock. No "Excuse me."

"Do you have a problem understanding the English language?" the colonel bellowed, ignoring my presence in the room. He had to be from a higher echelon since he was angrily addressing a superior officer. For the next 2 minutes, such a flurry of profanities emerged from the colonel's mouth that I became convinced he must have been a sailor or a marine in a previous life. My predecessor calmly stared at the colonel without changing his relaxed posture or saying a word. The interruption gratefully aroused me from my near-stuporous condition. It was apparent from the interspersed non-swear words in the colonel's tirade that the captain and his Navy medical unit had violated, and were continuing to violate, some rule at Camp Arifjan.

Satisfied that he had made his point, the lieutenant colonel departed. My predecessor and I simultaneously burst out laughing.

"Welcome to Kuwait, Jack."

"What was that all about?" I asked.

"Did you notice the 3 flagpoles out front? Occasionally, some of my sailors will run up a US flag and have someone snap their picture in front of the hospital with the flag in the background to send home."

"Yeah. So what?" I was not seeing an issue.

"Well, only one flag is to fly over Camp Arifjan, and that one flag is the US flag in front of the camp headquarters building."

I grasped the point immediately. I was going to be working in a rules-enriched, or infested, environment.

"Restricting military units from flying flags is un-American," I pointed out, smiling. "There has got to be a way to circumvent that rule."

"Good luck with that."

This was my introduction to Kuwait during my predeployment site survey (PDSS). I would spend 7 days in Kuwait, observing and understanding my tasking first-hand. I would be the commanding officer of EMF (expeditionary medical facility) Dallas, a unit of approximately 375 reserve sailors. We would staff the level 3 hospital at Camp Arifjan, located about 25 miles south of
Correspondence

Dr. Riggs

jriggs@wvu.edu

\section{ค Audio}

Listen to Dr. Riggs read this story.

NPub.org/i0jlwv 

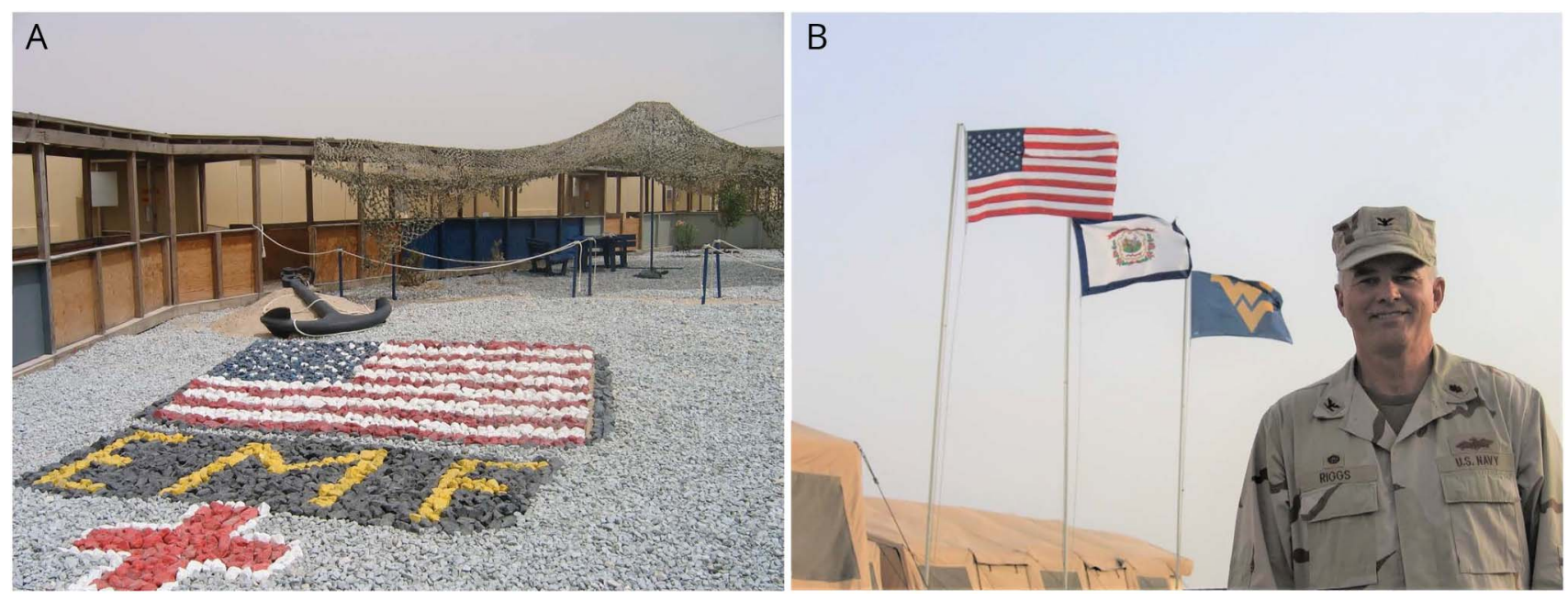

(A) Rock garden at US Military Hospital Kuwait with large US flag. (B) The author with 3 flags in the background flying over US Military Hospital Kuwait.

Kuwait City. This hospital was a combat support hospital, a CSH (pronounced CASH in army jargon), and was named US Military Hospital Kuwait.

Despite the gruesome seriousness of my mission, I had not forgotten the flag challenge when I returned to Kuwait 4 months later. If we could not fly a flag over the hospital, I would at least start by "flying" a flag on the ground. I asked my command master chief to see if enlisted personnel were interested in volunteering during their off-duty hours to work on a hospital "beautification" project. I envisioned a large rock garden that contained a large painted rock US flag. The project turned out better than I had imagined (figure, A). There was a tall light pole, illuminating the rock flag at night, ensuring its visibility to helicopter crews that brought in patients around the clock. However, this flag was not getting me any closer to my objective of freely and openly flying flags over the hospital.

I soon recognized that the hospital was a VIP magnet. Members of Congress, congressional staffers, entertainers, and senior military leaders were continuously visiting Camp Arifjan. Once there, they all wanted to visit the hospital so they could personally thank patients for their service and sacrifice. After walking through the hospital wards, these VIPs would gravitate to the US flag in the rock garden. There they would thank the doctors, nurses, and corpsmen for providing treatment and care to our service members. Invariably, they would have their pictures taken with hospital staff with the rock garden US flag in the foreground or background. Staff members from the various commands located at Camp Arifjan would always accompany VIPs, ensuring these visitors were getting the proper message.

\section{Eureka!}

VIPs were the key to solving my flag-flying dilemma.
Before each subsequent VIP visit, I would have a US flag run up our flagpole. I would then present that properly folded flag and a color certificate indicating that this flag flew over US Military Hospital Kuwait on the date of their visit and in honor and appreciation of their visit. The VIPs universally expressed gratitude for the gift. Camp Arifjan command staff members politely smiled through each flag presentation.

After about 6 such presentations, the chief of staff for the base commander approached me.

"Captain Riggs, we know what you are doing. We do not like it. But, we are not going to stop you.”

Objective achieved!

I informed my staff that they could start flying flags whenever they wanted. Multiple flags would fly every day. Unit members sent flags and certificates home in honor of birthdays, anniversaries, holidays, and almost any occasion one could imagine. I personally bought 3 flags and had them shipped to Kuwait. I flew them over the hospital on the Fourth of July (figure, B). Those flags have a special meaning for me, and I will proudly possess them until the day I die.

Within a couple of weeks, all sorts of flags began flying over Camp Arifjan. The reasoning was quite simple. If a Navy medical unit can fly flags with impunity, then any unit can.

On one unimaginably tragic occasion, the Ambassador to Kuwait and the Defense Minister from one of our coalition nations were at our hospital to observe and inspect the body of one of their soldiers. When the body left the hospital at $1 \mathrm{AM}$, about 50 US sailors rendered honors to his US flagdraped body in front of these 2 distinguished visitors. The 
Ambassador and Defense Minister did not appear to be offended and said nothing. Considering all that had transpired the previous day in Iraq, the gesture was likely more helpful than harmful. I had that flag flown over the hospital and had a certificate printed up for the soldier's mother expressing our deepest sympathy over the loss of her son. I sent that flag and certificate to the Ambassador, who in turn had them delivered to the soldier's mother. A few weeks later, the Ambassador let us know how appreciative the soldier's mother was for the respect and honor shown to her son's body and for the gift of the flag that had draped her son's body.

One Sunday afternoon late in our rotation, I received a call from camp headquarters: "Captain Riggs, you have been flying the Christian flag over the hospital all day-would you please take it down. After all, this is a Muslim country, and you need to exercise some cultural sensitivity."

The chaplain flew his flag when he was conducting Sunday morning church services and had obviously forgotten to take the flag down.

"Yes, sir. I will have the flag taken down immediately. I am responsible for that oversight, and I will see to it that it never happens again.”

I could not believe my ears. They had asked nicely. I wished my predecessor could have heard that request. 


\title{
Neurology
}

\author{
$O$, say does that star spangled banner yet wave \\ Jack E. Riggs \\ Neurology 2018;90;1029-1031 \\ DOI 10.1212/WNL.0000000000005604
}

This information is current as of May 28, 2018

$\begin{array}{ll}\begin{array}{l}\text { Updated Information \& } \\ \text { Services }\end{array} & \begin{array}{l}\text { including high resolution figures, can be found at: } \\ \text { http://n.neurology.org/content/90/22/1029.full }\end{array} \\ \text { Subspecialty Collections } & \text { This article, along with others on similar topics, appears in the } \\ \text { following collection(s): } \\ \text { All Education } \\ \text { http://n.neurology.org/cgi/collection/all_education } \\ \text { All Ethics in Neurology/Legal issues } \\ \text { http://n.neurology.org/cgi/collection/all_ethics_in_neurology_legal_iss } \\ \text { ues } \\ \text { All Trauma } \\ \text { http://n.neurology.org/cgi/collection/all_trauma } \\ \\ \text { Information about reproducing this article in parts (figures,tables) or in } \\ \text { its entirety can be found online at: } \\ \text { http://www.neurology.org/about/about_the_journal\#permissions } \\ \text { Information about ordering reprints can be found online: } \\ \text { hermissions \& Licensing } \\ \text { http://n.neurology.org/subscribers/advertise }\end{array}$

Neurology ${ }^{\circledR}$ is the official journal of the American Academy of Neurology. Published continuously since 1951, it is now a weekly with 48 issues per year. Copyright (O 2018 American Academy of Neurology. All rights reserved. Print ISSN: 0028-3878. Online ISSN: 1526-632X.

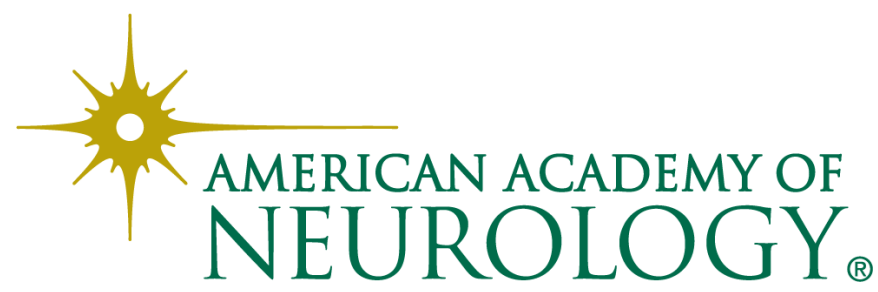

